\title{
EDUCORETAX
}

Volume 1 No. 4, Desember 2021

\section{ANALISIS BIBLIOMETRIK ATAS PENELITIAN BELANJA PERPAJAKAN (TAX EXPENDITURES) MENGGUNAKAN APLIKASI VOSVIEWER}

\author{
Purwanto \\ p.purwanto@pknstan.ac.id, Politeknik Keuangan Negara STAN
}

\begin{abstract}
Tax expenditures have reduced tax revenue from certain group of taxpayers. It has attracted many scholars to conduct studies in this field. So far there has been no biblioimetric analysis of tax expenditure research papers. The purpose of this study was to analyze the classification of tax expenditure research, identify trend of topics in tax expenditure research, and analyze opportunities for tax expenditure research topics in the future. Five-step bibliometric analysis method was adopted and the selected articles were analyzed with VOSviewer application. Searching for research papers was conducted with Publish or Perish application with the keyword "tax expenditure" in the title section from Scopus database published in the year 2001 - 2021 (20 year period) and 52 articles were obtained. The first result of VOSviewer analysis, network visualization, showed that research in tax expenditures can be classified into four clusters. The first cluster consists of 6 keywords, the second consists of 6 keywords, the third consists of five keywords, and the fourth consists of three keywords. The second result of VOSviewer analysis, overlay visualization, showed that trend of research topics for 2007-2008 werre 'local government', 'tax policy', and 'contribution'; trend of research topics for 2013-2015 were 'tax deduction', 'income', 'health', 'tax credit', and 'tax incentive'; and the trend of research topics for 2020-2021 were 'social expenditure' and 'tax benefit'. The third result of VOSviewer analysis, density visualization, revealed that topic of 'tax break' and 'tax allowance" were still rarely studied and can be alternatives for future research topics.

Keywords : belanja perpajakan, analisis bibliometrik, Publish or Perish, VOSviewer, Scopus
\end{abstract}

\begin{abstract}
Abstrak
Belanja perpajakan menyebabkan berkurangnya penerimaan pajak dari sebagian wajib pajak tertentu. Hal ini telah menarik banyak cendekia untuk melakukan studi bidang ini. Sejauh ini belum terdapat analisis bibliometrik atas artikel penelitian belanja perpajakan. Tujuan penelitian ini adalah menganalisis klasifikasi artikel penelitian belanja perpajakan, mengidentifikasi tren topik dalam penelitian belanja perpajakan, dan menganalisis peluang topik penelitian belanja perpajakan di masa yang akan datang. Metode penelitian digunakan metode lima langkah analisis bibliometrik dan data analisis digunakan aplikasi VOSviewer. Penelusuran artikel digunakan aplikasi Publish or Perish dengan kata kunci "tax expenditure" pada bagian judul dari database Scopus yang dipublikasikan tahun 2001 - 2021 (periode 20 tahun) dan diperoleh 52 artikel. Hasil analisis VOSviewer pertama, network visualization, menunjukkan artikel penelitian belanja perpajakan tersebut dapat diklasifikasikan menjadi empat klaster. Klaster pertama terdiri dari 6 kata kunci, klaster kedua terdiri dari 6 kata kunci, klaster ketiga terdiri dari lima kata kunci, dan klaster empat terdiri dari tiga kata kunci. Hasil analisis kedua VOSviewer, overlay visualization, menunjukkan bahwa tren topik penelitian pada tahun 2007-2008 adalah 'local government', 'tax policy', dan 'contribution'; tren topik penelitian tahun 2013-2015 adalalah 'tax deduction', 'income', 'health', 'tax credit', dan 'tax incentive'; dan tren topik penelitian tahun 2020-2021 adalah 'social expenditure' dan 'tax benefit'. Hasil analisis VOSviewer ketiga, density visualization, menunjukkan bahwa topik 'tax break' dan 'tax allowance' masih jarang diteliti sehingga menjadi peluang topik penelitian di masa yang akan datang.
\end{abstract}

Kata Kunci : belanja perpajakan, analisis bibliometrik, Publish or Perish, VOSviewer, Scopus

\section{PENDAHULUAN}

Beberapa tahun terakhir belanja perpajakan (tax expenditures) menjadi perhatian dari pemerintah Indonesia. Belanja perpajakan merupakan hilangnya penerimaan pajak sehubungan dengan ketentuan pajak dapat berupa pengecualian, pembebasan, pengurangan penghasilan, kredit pajak, tarif pajak preferensial, serta penundaan utang pajak (Burton, M., \& Sadiq, 2013, p.19). Dampak belanja perpajakan terhadap APBN pada hakekatnya sama dengan belanja subsidi pemerintah. Tidak seperti belanja subsidi, ketika ketentuan belanja perpajakan sudah diundangkan, belanja perpajakan tidak memerlukan persetujuan dari pemerintah dan DPR setiap tahun.

Nilai belanja perpajakan Indonesia dari tahun ke tahun menunjukkan peningkatan. Nilai belanja perpajakan tidak dapat dihitung secara pasti, sehingga hasil perhitungan hanya berupa 


\section{EDUCORETAX}

Volume 1 No. 4, Desember 2021

estimasi. Tabel 1 menggambarkan laporan belanja perpajakan Indonesia dari tahun 2016 sampai dengan 2019. Estimasi nilai belanja perpajakan meningkat dari Rp 192,5 triliun di tahun 2016 menjadi Rp 257,2 triliun di tahun 2019. Dalam persentase terhadap produk domestik bruto, belanja perpajakan meningkat dari $1.55 \%$ di tahun 2016 menjadi $1.62 \%$ di tahun 2019 .

Tabel 1 Belanja Perpajakan Indonesia

\begin{tabular}{lrrrr|}
\hline \multirow{2}{*}{ Jenis pajak } & \multicolumn{4}{c}{ Estimasi } \\
\cline { 2 - 5 } & \multicolumn{1}{c}{ 2016 } & 2017 & 2018 & \multicolumn{1}{c|}{2019} \\
\hline PPN dan PPnBM & 116.326 & 132.848 & 142.811 & 166.920 \\
Pajak Penghasilan & 67.674 & 54.350 & 70.103 & 79.222 \\
Bea Masuk dan Cukai & 8.549 & 9.548 & 12.166 & 11.027 \\
PBB sektor P3 & 14 & 75 & 75 & 57 \\
Bea Materai & 0 & 0 & 0 & 0 \\
\hline Total & 192.563 & 196.821 & 225.155 & 257.226 \\
\hline & $\%$ terhadap PDB & & \\
\hline PPN dan PPnBM & $0.94 \%$ & $0.98 \%$ & $0.96 \%$ & $1.05 \%$ \\
Pajak Penghasilan & $0.55 \%$ & $0.40 \%$ & $0.47 \%$ & $0.50 \%$ \\
Bea Masuk dan Cukai & $0.07 \%$ & $0.07 \%$ & $0.08 \%$ & $0.07 \%$ \\
PBB sektor P3 & $0.00 \%$ & $0.00 \%$ & $0.00 \%$ & $0.00 \%$ \\
Bea Materai & $0.00 \%$ & $0.00 \%$ & $0.00 \%$ & $0.00 \%$ \\
\hline Total & $1.55 \%$ & $1.45 \%$ & $1.52 \%$ & $1.62 \%$ \\
\hline
\end{tabular}

Sumber : Laporan Belanja Perpajakan 2019 ((Badan Kebijakan Fiskal, 2020)

Dibandingkan dengan negara lain, rasio perpajakan Indonesia masih rendah. Grafik 1 menunjukkan bahwa tax ratio Indonesia dari tahun 2015 - 2019 berfluktuasi dari $11.6 \%$ 10.7\%. Menurut OECD (2021), tax ratio Indonesia jauh lebih rendah dibanding dengan tax ratio negara-negara Asia Pasifik 22.0\% dan negara-negara OECD 22.3\%. Rata-rata rasio belanja perpajakan terhadap PDB sebesar $1.54 \%$ menunjukkan bahwa nilai belanja perpajakan merupakan jumlah yang cukup signifikan. Pemerintah perlu berhati-hati dalam merumuskan kebijakan belanja perpajakan. Kebijakan belanja perpajakan perlu dirumuskan dan dievaluasi supaya tujuan dari kebijakan tersebut tercapai. Oleh karena itu, perlu dilakukan penelitian untuk mengevaluasi dan merumuskan kebijakan belanja perpajakan.

Beberapa negara maju sudah memberikan perhatian terhadap belanja perpajakan mulai tahun 1960-an (International Monetary Fund, 2007). Jerman dan Amerika Serikat adalah negara pertama yang membuat laporan belanja perpajakan. Korea Selatan mulai menyusun laporan belanja perpajakan tahun 1999. Beberapa negara menyusun laporan belanja perpajakan dalam laporan tersendiri atau bagian dari dokumen anggaran negara.

Banyak peneliti yang sudah melakukan studi belanja perpajakan. Penelitian pertama belanja perpajakan yang diterbitkan di jurnal terindeks Scopus adalah di tahun 1975 (Harriss, 1975). Jumlah penelitian belanja perpajakan yang diterbitkan di jurnal terindeks Scopus selama tahun 1975 - 2021 sebanyak 97 artikel dan selama tahun 2001 - 2021 sebanyak 52 artikel. Sampai saat ini belum ada kajian analisis bibliometrik atas artikel riset belanja perpajakan. Oleh karena itu, penelitian ini mengisi kekosongan tersebut dengan melakukan analisis bibliometrik atas artikel riset belanja perpajakan. Tujuan penelitian ini adalah menganalisis klasifikasi penelitian belanja perpajakan, mengidentifikasi tren topik penelitian belanja perpajakan, dan menganalisis peluang topik penelitian belanja perpajakan di masa yang akan datang. 


\section{EDUCORETAX}

Volume 1 No. 4, Desember 2021

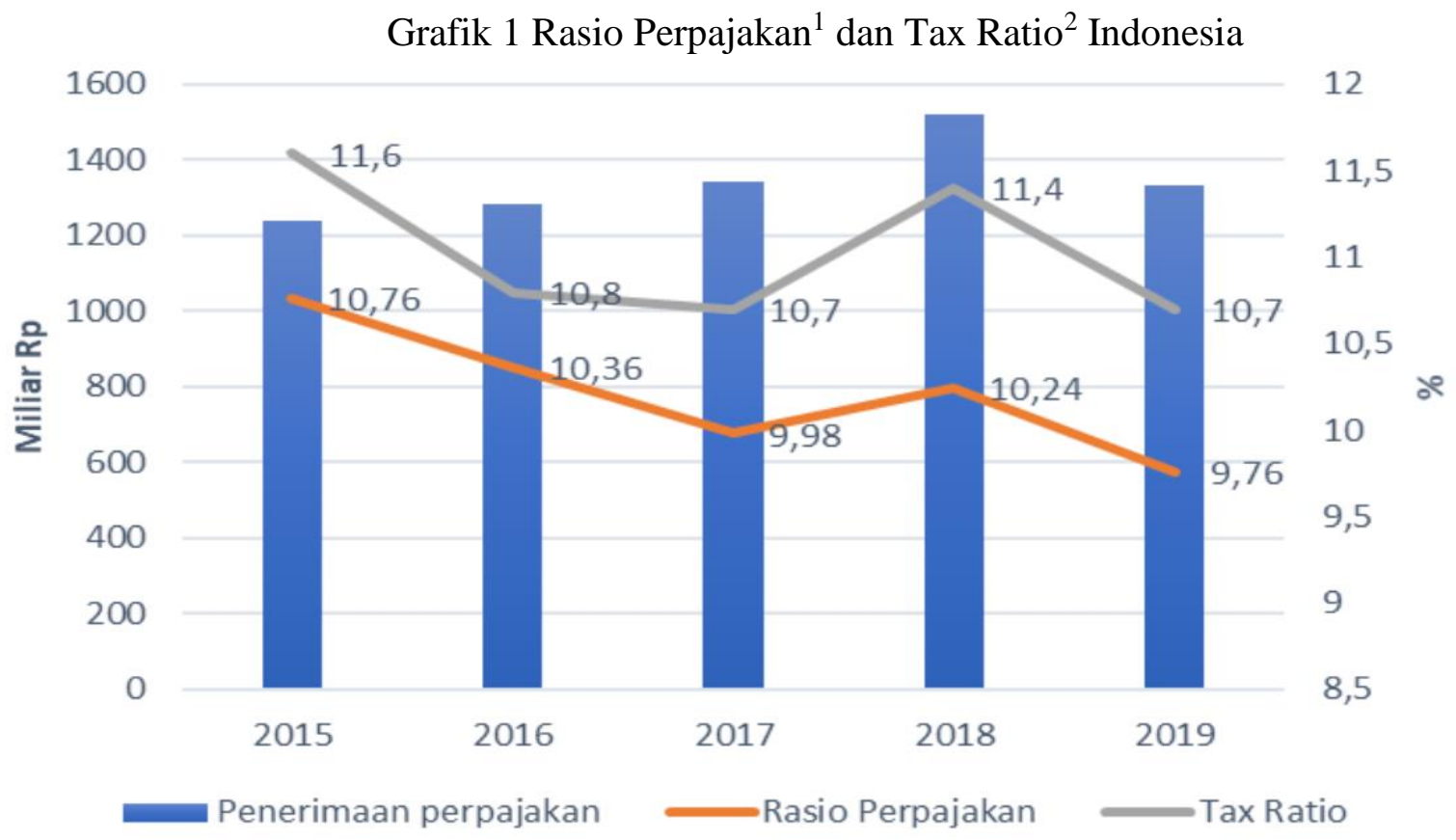

Sumber : Laporan Belanja Perpajakan 2019 (Badan Kebijakan Fiskal, 2020)

\section{KAJIAN PUSTAKA}

Konsep belanja perpajakan (tax expenditures) telah banyak memicu perdebatan diantara para cendekia. Perdebatan berkisar pada definisi, tujuan, cara mengidentifikasi atau mengukur belanja perpajakan. Konsep belanja perpajakan awalnya diperkenalkan untuk mendemonstrasikan kesamaannya dengan belanja pemerintah langsung (Burton, 2010 p.20). Belanja perpajakan adalah transfer sumber daya publik untuk mengurangi kewajiban pajak selain melalui belanja langsung (Kraan, 2004). Selanjutnya, menurut Anderson \& Minarik (2006), belanja pajak adalah peraturan atau praktik yang mengurangi atau menunda penerimaan pajak bagi sebagian wajib pajak tertentu.

OECD (2010 p.12) menggolongkan belanja perpajakan dalam beberapa jenis, yaitu allowances, pembebasan pajak, keringanan tarif pajak, penundaan pajak, dan kredit pajak. Belanja perpajakan tidak hanya terdapat pada Pajak Penghasilan, tetapi bisa terdapat pada semua jenis pajak (Badan Kebijakan Fiskal, 2020). Tujuan dari kebijakan belanja perpajakan adalah sebagai salah satu instrument pemerintah untuk mencapai tujuan sosial dan tujuan ekonomi (Burton, 2010 p.18).

\section{METODE PENELITIAN}

Penelitian ini merupakan analisis bibliometrik. Reviu literatur dilakukan dengan metode yang sistematis, eksplisit, dan dapat direplikasi (Fink, 2005; Garza-Reyes, 2015), atau metode pemetaan atas struktur ilmu pengetahuan tertentu (Tranfield et al., 2003). Analisis bibliometrik merupakan bagian dari reviu literatur. Analisis bibliometrik biasanya digunakan untuk menganalisis artikel jurnal, buku atau dokumen ilmiah tertulis lainnya (Heersmink et al., 2010).

Tujuan analisis bibliometrik adalah menghasilkan ikhtisar dari sejumlah data kepustakaan untuk menyajikan perkembangan terkini dari struktur ilmu pengetahuan dan tren penelitian atas topik tertentu (Donthu et al., 2021). Dalam studi ini digunakan lima langkah

\footnotetext{
${ }^{I}$ Rasio perpajakan merupakan rasio antara total penerimaan perpajakan pemerintah pusat dibandingkan dengan PDB Nominal

${ }^{2}$ Tax ratio merupakan rasio antara total penerimaan perpajakan pemerintah pusat,PNBP SDA Migas, dan PNBP SDA Pertambangan Umum dibandingkan dengan PDB Nominal
} 


\section{EDUCORETAX}

Volume 1 No. 4, Desember 2021

metode analisis bibliometri yang diperkenalkan oleh Fahimnia et al. (2015). Kelima langkah tersebut adalah melakukan penelusuran awal, menyajikan hasil penelusuran awal, mempersempit hasil penelusuran, menyajikan diskripsi statistik hasil penelusuran akhir, dan melakukan analisis data.

Pada penelitian ini, langkah pertama berupa penelusuran awal dokumen kepustakaan dilakukan pada bulan September 2021. Penelusuran dilakukan menggunakan aplikasi Publish or Perish dari database Scopus. Kata kunci "tax expenditure" diinput pada bagian judul dan tahun penerbitan tidak dibatasi.

Langkah kedua adalah penyajian hasil penelusuran awal ini. Pada penelusuran awal tahun penerbitan tidak dibatasi. Dari penelusuran awal diperoleh 128 dokumen, yang terdiri dari artikel, buku, konferensi paper, surat, monograf, dan reviu editorial/buku, yang diterbitkan selama 1975 - 2021 atau jangka waktu 46 tahun. Penelusuran dilanjutkan dengan kata kunci "tax expenditures" pada bagian judul dari database yang sama. Hasil penelusuran adalah sama dengan kata kunci "tax expenditure”. Database Scopus digunakan karena memiliki kredibilitas bagus dan sudah dikenal luas. Tabel 2 menyajikan sepuluh dokumen yang paling banyak disitasi dari hasil penelusuran awal.

Tabel 2 Daftar Sepuluh Dokumen Sitasi Terbanyak

\begin{tabular}{|l|l|c|}
\hline \multicolumn{1}{|c|}{ Penulis } & \multicolumn{1}{|c|}{ Judul } & $\begin{array}{c}\text { Tahun } \\
\text { Penerbitan }\end{array}$ \\
\hline J. Poterba & $\begin{array}{l}\text { Tax expenditures for owner-occupied housing: Deductions for } \\
\text { property taxes and mortgage interest and the exclusion of imputed } \\
\text { rental income }\end{array}$ & 2008 \\
\hline D. Dalenberg & $\begin{array}{l}\text { The Effects of Taxes, Expenditures, and Public Infrastructure on } \\
\text { Metropolitan Area Employment }\end{array}$ & 1995 \\
\hline A. Stebbing & $\begin{array}{l}\text { Universal welfare by other means? Social tax expenditures and the } \\
\text { Australian dual welfare state }\end{array}$ & 2010 \\
\hline E. Saez & The optimal treatment of tax expenditures & 2004 \\
\hline D. Bails & $\begin{array}{l}\text { The Effectiveness of Tax-Expenditure Limitations: A Re- } \\
\text { evaluation: In 19 States They Resulted in Virtually No Success in } \\
\text { Limiting Growth in Their Budgets }\end{array}$ & 1990 \\
\hline L. Burman & $\begin{array}{l}\text { How big are total individual income tax expenditures, and who } \\
\text { benefits from them? }\end{array}$ & 2008 \\
\hline D. Bails & A critique on the effectiveness of tax-expenditure limitations & 1982 \\
\hline C. Faricy & $\begin{array}{l}\text { Public Attitudes Toward Social Spending in the United States: The } \\
\text { Differences Between Direct Spending and Tax Expenditures }\end{array}$ & 2014 \\
\hline N. Eissa & Redistribution and tax expenditures: The earned income tax credit & 2011 \\
\hline B. Greve & $\begin{array}{l}\text { The hidden welfare state, tax expenditure and social policy A } \\
\text { comparative overview }\end{array}$ & 1994 \\
\hline Artkel yang & ping banya distasi (jumah sitasi 76$)$ adah yang diterb \\
\hline
\end{tabular}

Artikel yang paling banyak disitasi (jumlah sitasi 76) adalah yang diterbitkan American Economic Review pada tahun 2008 yang ditulis oleh J. Poterba dengan judul "Tax expenditures for owner-occupied housing: Deductions for property taxes and mortgage interest and the exclusion of imputed rental income".

Langkah berikutnya adalah mempersempit hasil penelusuran. Dalam tahap ini tahun penerbitan dibatasi 20 tahun terakhir, yaitu tahun 2001 - 2021. Hasil penelusuran dengan kata kunci dan database yang sama diperoleh 84 dokumen terdiri dari artikel, buku, konferensi paper, 


\section{EDUCORETAX}

Volume 1 No. 4, Desember 2021

surat, catatan, dan reviu editorial/buku. Tabel 3 menyajikan 84 dokumen hasil penelusuran kedua.

Tabel 3 Hasil Penelusuran kedua

\begin{tabular}{|c|c|}
\hline Jenis Dokumen & Jumlah Dokumen \\
\hline Buku & 15 \\
\hline Conference paper & 6 \\
\hline Monograf & 1 \\
\hline Reviu buku/editorial & 10 \\
\hline Artikel & 52 \\
\hline Jumlah & 84 \\
\hline
\end{tabular}

Untuk mendapatkan hasil analisis yang kredibel, analisis bibliometrik ini hanya akan dilakukan terhadap artikel hasil penelitian yang diterbitkan di jurnal yang terindeks Scopus. Dari 84 dokumen hasil penelusuran untuk tahun penerbitan 2001 - 2021, sebanyak 15 berupa buku, 6 berupa conference paper, 1 monograf, 10 berupa reviu buku/editorial, dan 52 artikel. Artikel tersebut diunduh dan disimpan dengan format file RIS. Selanjutnya, metadata file RIS dibuka menggunakan aplikasi Mendeley untuk dilengkapi data abstrak dan kata kunci artikel.

Langkah keempat berupa penyajian data statistik hasil seleksi akhir. Hasil akhir penelusuran dengan kata kunci "tax expenditure" menggunakan aplikasi Publis or Perish dengan database Scopus untuk penerbitan 2001 - 2021 diperoleh 52 artikel. Jumlah artikel yang diterbitkan per tahun disajikan pada grafik 2. Grafik 2 menunjukkan bahwa dari tahun $2001-$ 2009 jumlah publikasi rata-rata satu artikel. Jumlah penerbitan terbanyak terjadi di tahun 2011 dan 2018. Tahun 2012 - 2016 jumlah penerbitan hanya satu per tahun, kecuali tahun 2014 sebanyak empat. Data yang menarik adalah jumlah penelitian mulai tahun 2018 - 2021 yang meningkat lebih tinggi dibanding tahun-tahun sebelumnya. Hal ini menunjukkan bahwa mulai tahun 2018 sampai saat ini jumlah penelitian belanja perpajakan lebih banyak dilakukan.

Grafik 2 Jumlah Publikasi per Tahun

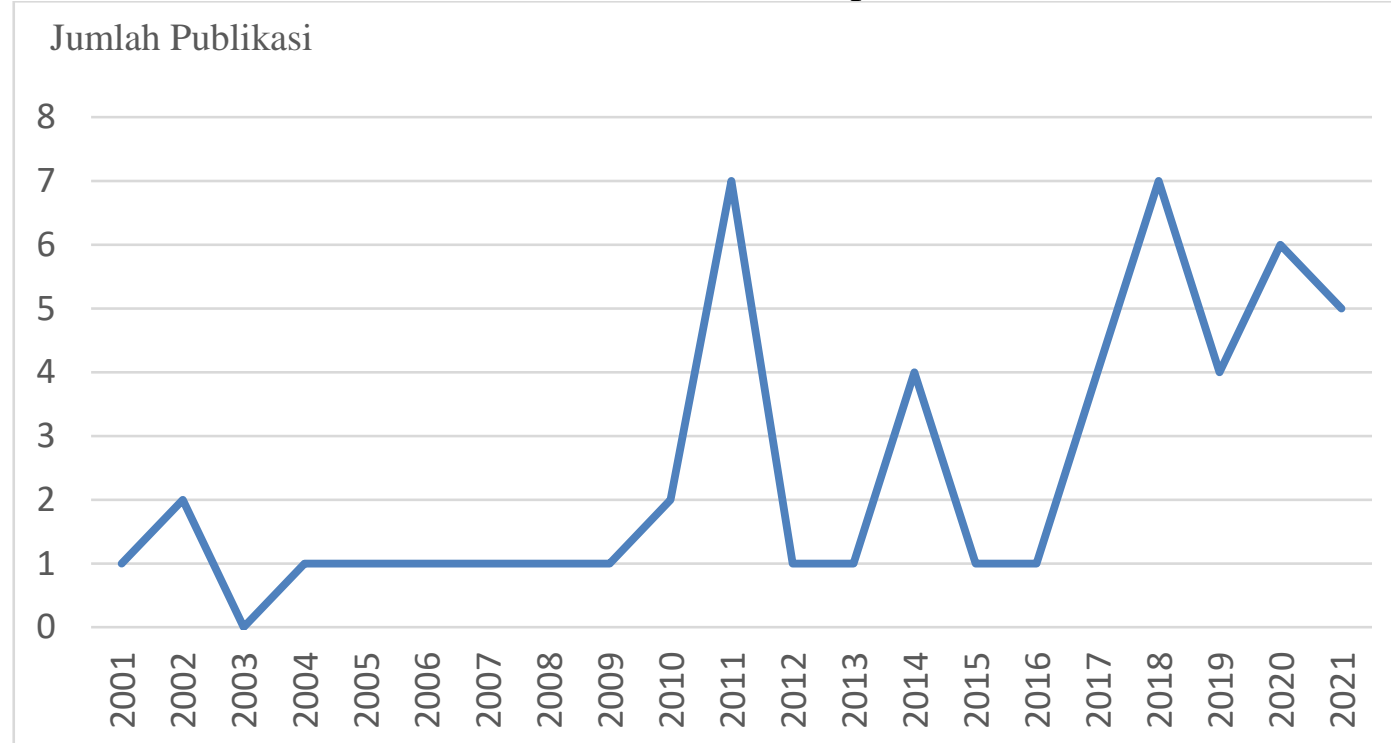

Sumber : hasil penelusuran terakhir diolah oleh penulis

Grafik 3 menyajikan jumlah artikel yang diterbitkan dari setiap jurnal. Selama tahun 2001 - 2021, National Tax Journal menerbitkan 8 artikel, diikuti oleh Journal of European Social Policy, Public Budgeting and Finance, Public Finance Review, Tax Policy and the 


\section{EDUCORETAX}

Volume 1 No. 4, Desember 2021

Economy, Cienciae Sude Cojetiva masing-masing 2 artikel, sedangkan jurnal lainnya hanya menerbitkan satu artikel. Hal ini menunjukkan bahwa National Tax Journal menjadi pilihan favorit peneliti untuk menerbitkan hasil penelitiannya.

Grafik 3 Jumlah Publikasi Artikel per Jurnal

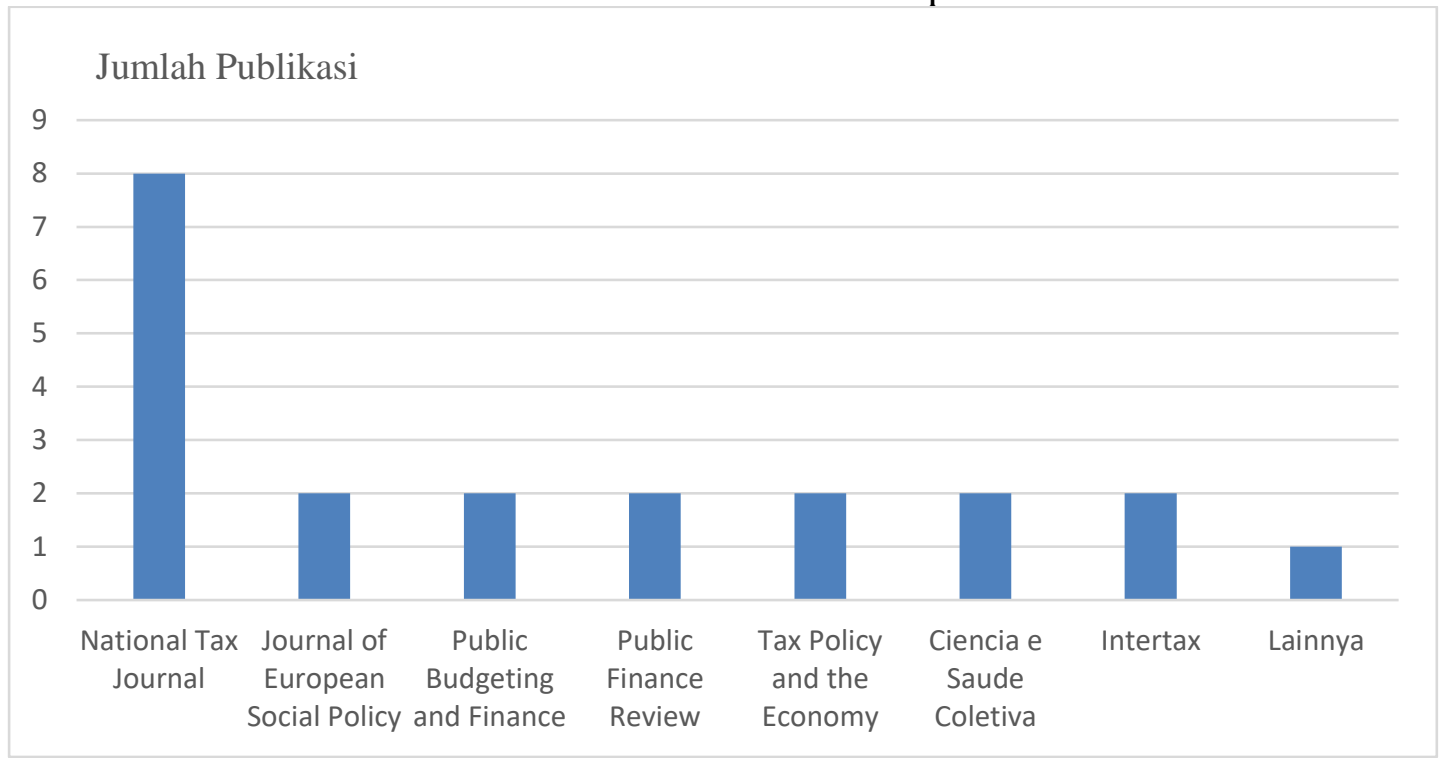

Sumber : hasil penelusuran terakhir diolah oleh penulis

Grafik 4 menyajikan sepuluh jurnal dengan sitasi per artikel tertinggi. Beberapa jurnal masuk dalam sitasi per artikel tertinggi, tetapi dalam waktu 20 tahun hanya menerbitkan satu artikel, kecuali National Tax Journal dan Journal of European Social Policy. Artikel dengan sitasi tertinggi (43) diterbitkan Journal of Social Policy dengan judul Universal welfare by other means? Social tax expenditures and the Australian dual welfare state. Sitasi tertinggi berikutnya (41 sitasi) adalah artikel berjudul The optimal treatment of tax expenditures yang diterbitkan pada Journal of Public Economics.

Grafik 4 Sepuluh Jurnal Sitasi per Artikel Tertinggi

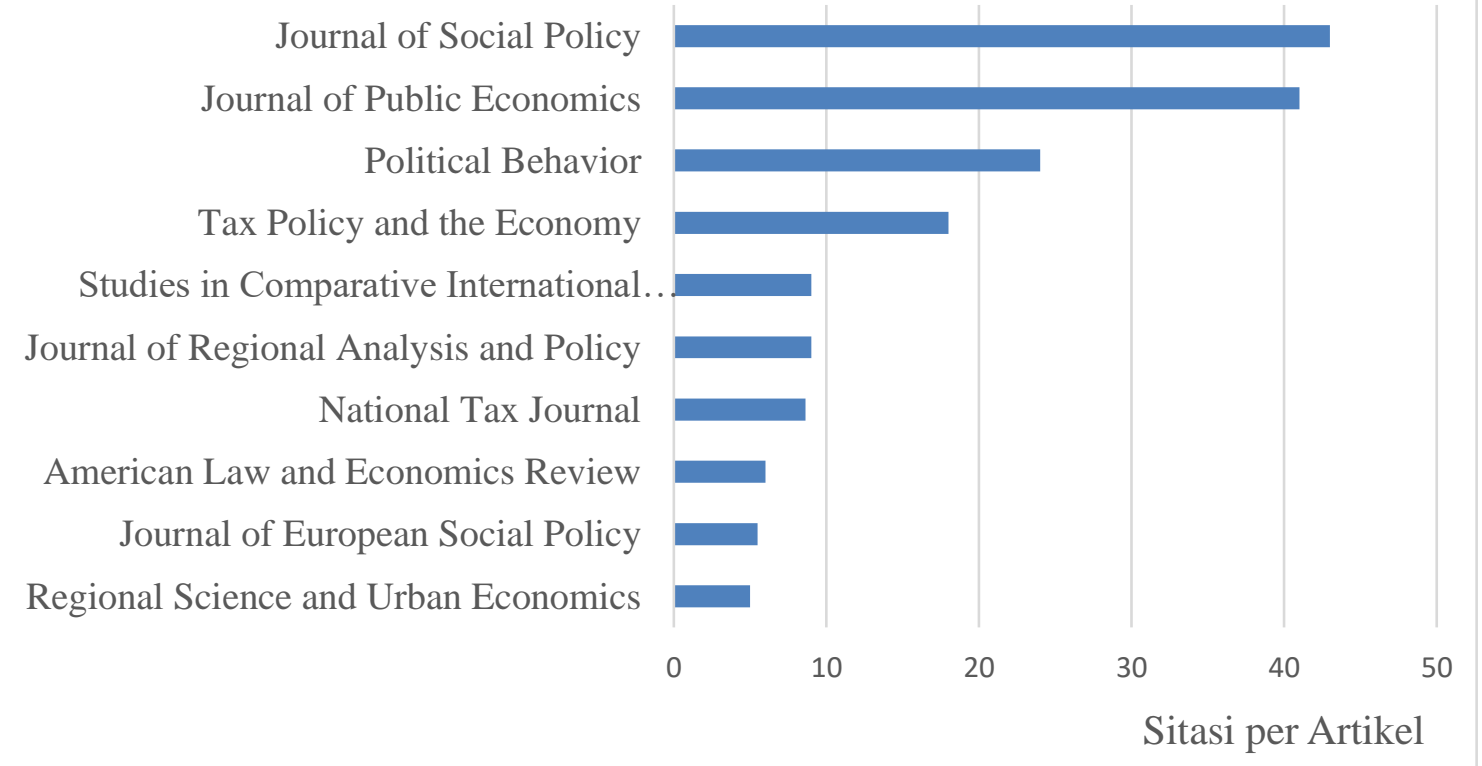

Sumber : hasil penelusuran terakhir diolah oleh penulis

Langkah terakhir dalam analisis bibliometrik adalah adalah analisis data. Analisis bibliometrik ini dilakukan terhadap artikel penelitian yang diterbitkan pada jurnal yang terindeks Scopus. Penelusuran dilakukan menggunakan aplikasi Publish or Perish versi 


\section{EDUCORETAX}

Volume 1 No. 4, Desember 2021

8.1.3625.7987 dengan kata kunci "tax expenditure" pada judul. Hasil penelusuran awal tanpa membatasi tahun penerbitan mendapatkan 128 dokumen yang diterbitkan selama tahun $1975-$ 2021 atau 46 tahun. Agar diperoleh artikel penelitian yang lebih relevan, tahun penerbitakan dibatasi 20 tahun terakhir atau 2001 - 2021 dan diperoleh 84 dokumen, yang terdiri dari artikel, buku, paper conference, monograf, dan reviu editorial/buku. Dari 84 dokumen tersebut yang berupa artikel adalah 52 sehingga analisis bibliometrik ini dilakukan terhadap 52 artikel tersebut. Tabel 4 menggambarkan perbandingan hasil penelusuran awal dan penelusuran akhir.

Tabel 4 Perbandingan Hasil Penelusuran Awal dan Penelusuran Akhir

\begin{tabular}{|l|c|c|}
\hline \multicolumn{1}{|c|}{ Data Metriks } & Penelusuran Awal & Penelusuran Akhir \\
\hline Kata kunci & "tax expenditure" & "tax expenditure" \\
\hline Sumber & Database Scopus & Database Scopus \\
\hline Tahun penerbitan & $1975-2021$ atau 46 tahun & $2001-2021$ atau 20 tahun \\
\hline Dokumen & 128 & 84 \\
\hline Artikel & 97 & 52 \\
\hline Jumlah sitasi & 769 & 480 \\
\hline Sitasi per tahun & 16.72 & 24 \\
\hline
\end{tabular}

Hasil penelusuran awal menunjukkan dalam kurun waktu 46 tahun terdapat 97 artikel yang diterbitkan atau rata-rata 2.11 per tahun, sedangkan hasil penelusuran akhir dalam 20 tahun diterbitkan 52 artikel atau rata-rata 2.60 per tahun. Hal ini menunjukkan bahwa penelitian terkait belanja pajak masih rendah, tetapi jumlahnya meningkat walaupun tidak signifikan. Namun, grafik 2 menunjukkan bahwa mulai tahun 2018 - 2021 penelitian terkait belanja perpajakan menunjukkan peningkatan dibandingkan tahun-tahun sebelumnya.

Selanjutnya, hasil penelusuran awal disitasi sebanyak 769 untuk periode 46 tahun sehingga rata-rata sitasi per tahun adalah 16.72. Hasil penelusuran akhir disitasi sebanyak 480 untuk periode 20 tahun sehingga rata-rata sitasi per tahun adalah 24 . Hal ini menunjukkan bahwa dokumen yang diterbitkan selama 20 tahun terakhir memiliki dampak metrik lebih besar dalam jumlah sitasi.

\section{HASIL DAN PEMBAHASAN}

Setelah menganalisis rata-rata jumlah artikel dan sitasi per tahun, 52 artikel hasil penelusuran akhir dianalisis menggunakan aplikasi VOSviewer versi 1.6.17. VOSviewer dapat digunakan untuk melakukan klasterisasi publikasi ilmiah dan menganalisis hasil klasterisasi (van Eck \& Waltman, 2017).

Langkah pertama dilakukan ekstraksi data dari judul dan abstrak 52 artikel menggunakan VOSviewer. Dari ekstraksi data diperoleh 1333 term, dengan pilihan occurance 5, terdapat 49 term yang memenuhi. Dari 49 term dilakukan seleksi untuk mengeluarkan katakata yang kurang relevan. Istilah-istilah berikut tidak relevan dan dikeluarkan dari daftar analisis, yaitu finding, case, author, state, study, lesson, analysis, government, type, article, country, expenditure, change, impact, tel, vehicle, Malaysia, size, difference, resource, effect, way, result, tax, paper, dan taxis.

VOSviewer menghasilkan pemetaan bibliometrik melalui tiga visualisasi, yaitu network visualization, overlay visualization, dan density visualization. Tujuan penelitian yang pertama, 


\section{EDUCORETAX}

Volume 1 No. 4, Desember 2021

yaitu menganalisis klasifikasi penelitian belanja perpajakan dapat dilihat dari hasil network visualization. Gambar 1 menunjukkan hasil pemetaan network visualization. Kata-kata kunci yang saling berhubungan digambarkan dengan empat warna yang berbeda. Masing-masing warna menggambarkan satu klaster. VOSviewer secara otomatis memetakan visualisasi 52 artikel penelitian menjadi empat klaster atau empat klasifikasi.

Gambar 1 Hasil Analisis Network Visualization

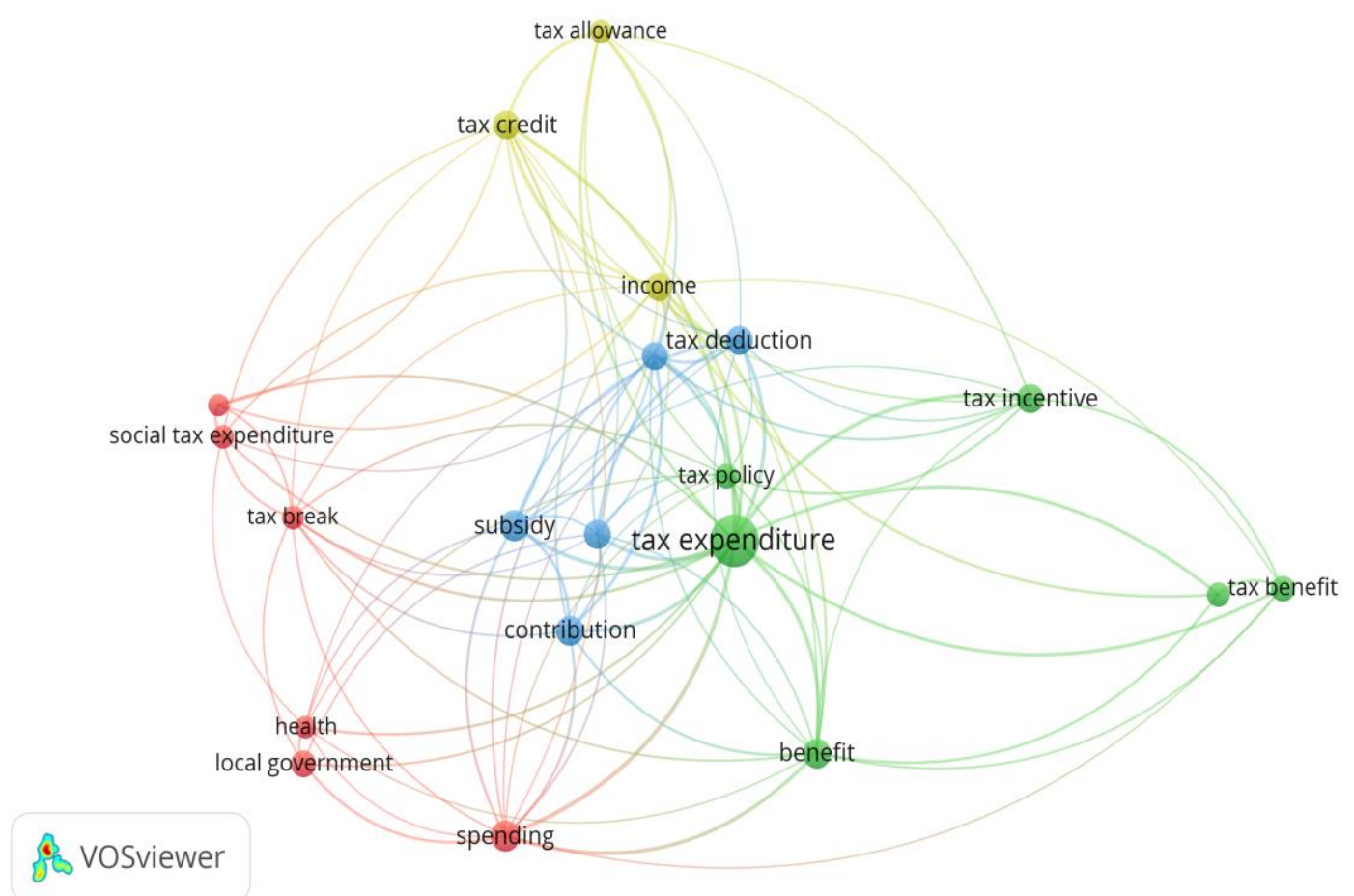

Klaster satu (warna merah) terdiri dari enam kata kunci yaitu health, local government, social protection, social tax expenditure, spending, dan tax break. Pada klaster satu kata kunci yang menunjukkan angka occurance tertinggi adalah 'spending', yaitu 19. Hal ini menunjukkan topik 'spending' paling sering diteliti di klaster satu. Dari kata kunci yang terdapat dalam klaster satu, penelitian belanja perpajakan dalam kelompok ini banyak dikaitkan dengan tujuan sosial dari kebijakan belanja perpajakan. Misalnya kata kunci health. Di Amerika Serikat, penghasilan tidak kena pajak (PTKP) dapat diberikan dalam bentuk itemized. Orang yang memiliki riwayat penyakit kronis, seperti hepatitis, diabetes, akan diberikan PTKP lebih besar, karena memerlukan biaya pengobatan rutin yang lebih tinggi. Saat ini di Indonesia menerapkan PTKP bentuk standardized. Direktorat Jenderal Pajak pernah mewacanakan bahwa PTKP Indonesia dalam bentuk itemized.

Klaster dua (warna hijau) terdiri dari enam kata kunci, yaitu benefit, private pension, tax benefit, tax expenditure, tax incentive, dan tax policy. Kata kunci yang memiliki angka occurance tertinggi setelah kata 'tax expenditure' adalah 'benefit', yaitu 16. Dari kata kunci yang terdapat pada klaster dua, penelitian pajak dalam kelompok ini banyak dikaitkan dengan topik penerima manfaat belanja perpajakan, misalnya pensiun. Di Indonesia sendiri, bidang pensiun banyak mendapatkan keringanan pajak. Misalnya saja, perusahaan yang membayar iuran pensiun untuk karyawannya. Iuran pensiun tersebut, tidak masuk unsur penghasilan yang dipotong Pajak Penghasilan (PPh) Pasal 21. Pengenaan $\mathrm{PPh}$ atas iuran pensiun yang dibayar perusahaan ditunda saat karyawan tersebut menerima pensiun. Selain itu, perusahaan dana pensiun menikmati berbagai pengecualian. Antara lain, penghasilan dana pensiun dari investasi 


\section{EDUCORETAX}

Volume 1 No. 4, Desember 2021

berupa bunga deposito, diskonto Sertifikat Bank Indonesia, bunga obligasi dan deviden saham yang diperdagangkan di bursa efek dikecualikan dari objek PPh.

Klaster tiga (warna biru) terdiri dari lima kata kunci, yaitu contribution, deduction, individual, subsidy, tax deduction. Kata kunci dengan angka occurance tertinggi adalah 'subsidy' , yaitu 19. Pada kelompok ketiga penelitian belanja pajak dikaitkan dengan topik sumbangan dan wajib pajak orang pribadi. Di Indonesia beberapa sumbangan bagi penerimanya bukan merupakan objek pajak, dan bagi perusahaan yang memberikan dapat dikurangkan dari penghasilan. Sebagai contoh, sumbangan fasilitas pendidikan, sumbangan penelitian, sumbangan penanggulangan bencana nasional, dan sumbangan wajib keagamaan seperti zakat.

Klaster empat (warna kuning) terdiri dari tiga kata kunci, yaitu income, tax allowance, tax credit. Pada klaster empat 'tax credit' memiliki angka occurance tertinggi, yaitu 13. Pada kelompok keempat penelitian belanja pajak lebih banyak dikaitkan dengan topik fasilitas perpajakan atau tujuan ekonomi. Sebagai contoh, di Indonesia bagi perusahaan yang melakukan investasi di bidang industri pionir akan diberikan fasilitas berupa tax allowance, yaitu $30 \%$ dari nilai investasi dapat dikurangkan dari penghasilan kena pajak, yang dibagi menjadi 6 tahun atau $5 \%$ per tahun.

Selain itu, garis pada network visualization menggambarkan kekuatan hubungan antar kata kunci tersebut. Semakin tebal garis tersebut, berarti kedua kata kunci tersebut lebih sering dilakukan dalam satu penelitian yang sama. Sebagai contoh antara 'tax expenditure' dan 'benefit' dihubungkan dengan garis tebal. Berarti kedua topik tersebut sering digunakan pada penelitian yang sama. Kata-kata kunci yang dihubungkan dengan garis tipis menggambarkan bahwa kedua topik tersebut jarang digunakan pada penelitian yang sama, misalnya saja 'income' dan 'tax benefit'. Kata-kata kunci yang tidak dihubungkan dengan garis mengambarkan kedua kata kunci tersebut tidak pernah digunakan dalam penelitian yang sama, misalnya 'spending' dan 'tax incentive'. Hal ini menunjukkan terdapat peluang kedua topik tersebut dihubungkan dalam satu penelitian.

Tujuan penelitian yang kedua, yaitu mengidentifikasi tren topik dalam penelitian belanja perpajakan dapat dilihat pada gaamber 2 hasil analisis overlay visualization. Warna yang semakin terang (kuning) menggambarkan bahwa kata kunci tersebut sering digunakan pada penelitian terkini (tahun 2019 - 2021). Warna yang semakin gelap (ungu) menggambarkan bahwa kata kunci tersebut banyak digunakan pada penelitian di awal tahun 2001-2003. Gambar 2 menunjukkan bahwa warna yang dominan adalah warna hijau dan warna kuning. Hal ini mengindikasikan bahwa pada awal tahun 2000-an penelitian terkait belanja perpajakan masih jarang dilakukan. Kata kunci 'local government', 'tax policy', dan 'contribution digambarkan dalam warna hijau agak tua. Ketiga topik tersebut banyak diteliti sekitar tahun 2007-2008. Warna hijau terang pada gambar 2 menunjukkan bahwa pada 2013-2015 banyak dilakukan penelitian belanja perpajakan dengan topik tax deduction, income, health, tax credit, dan tax incentive. Tahun 2020 dan tahun 2021 banyak dilakukan penelitian belanja perpajakan dengan topik 'social tax expenditure dan 'tax benefit' (warna kuning). 


\section{EDUCORETAX}

Volume 1 No. 4, Desember 2021

\section{Gambar 2 Hasil Analisis Overlay Visualization}

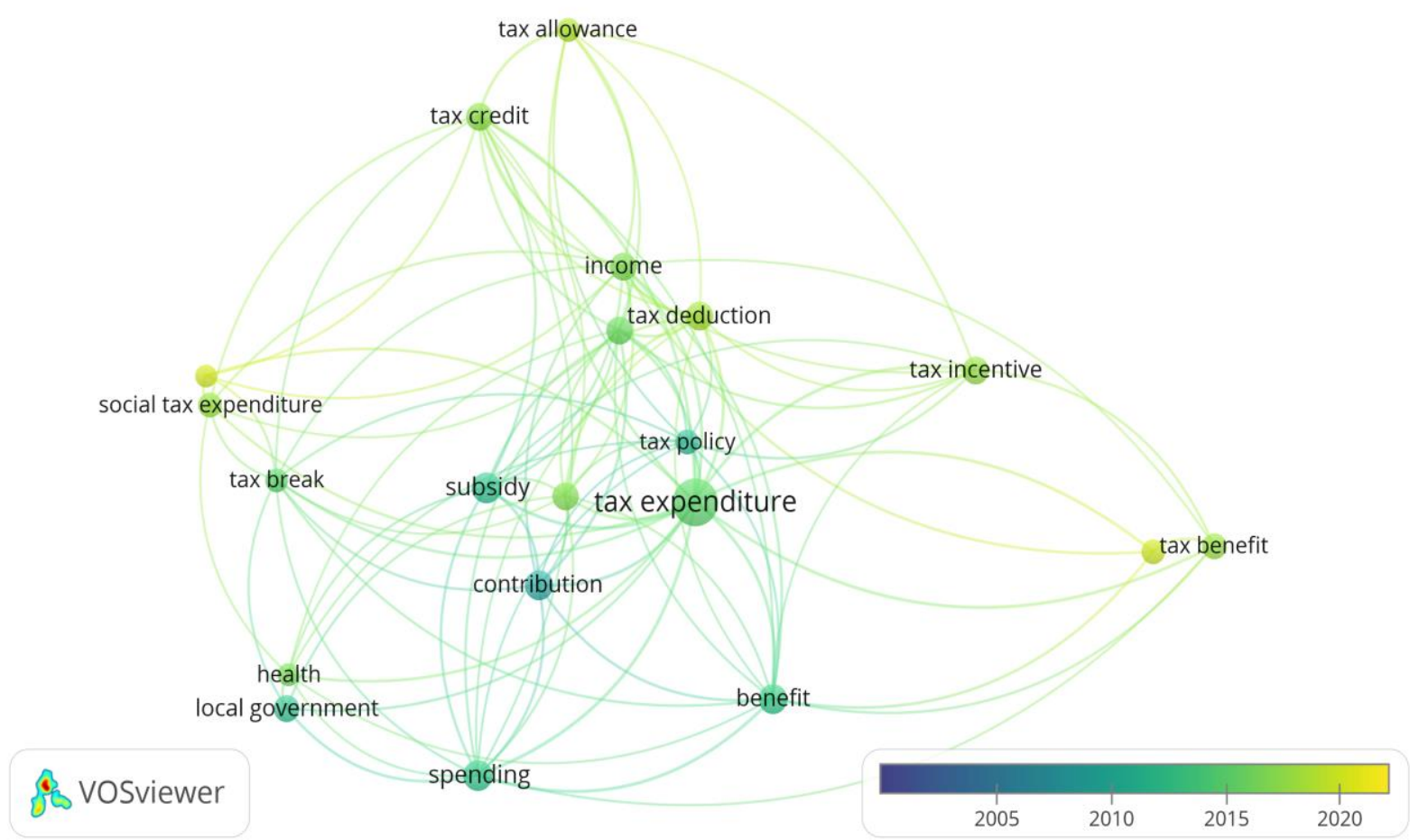

Tujuan penelitian ketiga, yaitu menganalisis peluang topik penelitian yang akan datang ditunjukkan pada gambar 3 hasil analisis density visualization. Semakin besar dan semakin terang visualisasi kata kunci tersebut menunjukkan bahwa topik tersebut sering diteliti. Gambar 3 menunjukkan "tax expenditure" digambarkan dengan visualisasi yang paling besar dan paling terang. Kata kunci tersebut paling sering muncul dalam penelitian karena memang merupakan topik utama 52 artikel yang dianalisis. Beberapa kata kunci yang digambarkan cukup terang adalah 'subsidy', 'tax deduction', 'contribution', dan 'income'. Topik-topik tersebut berarti sudah banyak diteliti. Kata kunci 'tax break' dan 'tax allowance' digambarkan kecil dan paling redup. Hal ini menunjukkan bahwa topik-topik tersebut masih jarang dilakukan penelitian sehingga masih terbuka peluang untuk dilakukan penelitian.

Selain menggunakan density visualization, peluang topik penelitian juga bisa dianalisis menggunakan network visualization pada gambar 1. Kedua kata kunci yang dihubungkan dengan garis tipis menunjukkan bahwa kedua topik tersebut jarang dihubungkan dalam penelitian yang sama. Dua kata kunci yang tidak dihubungkan dengan garis secara langsung menunjukkan kedua topik tersebut tidak pernah dihubungkan dalam satu penelitian yang sama. Sebagai contoh pada gambar 1 'tax incentive' dan 'spending' tidak dihubungkan dengan garis langsung. Kedua topik tersebut tidak pernah digunakan pada satu penelitian yang sama. Hal ini bisa menjadi peluang penelitian belanja perpajakan dikaitkan dengan tax incentive atau fasilitas pajak dan spending atau belanja APBN. Banyak fasilitas perpajakan yang dibiayai dari belanja subsidi pajak. Sebagai contoh fasilitas PPh Pasal 21 karyawan swasta ditanggung pemerintah selama masa pandemi covid-19. Dalam hal ini pemerintah mengalokasikan belanja subsidi pajak pada APBN untuk memberikan fasilitas $\mathrm{PPh}$ pasal 21 ditanggung pemerintah. 


\section{EDUCORETAX}

Volume 1 No. 4, Desember 2021

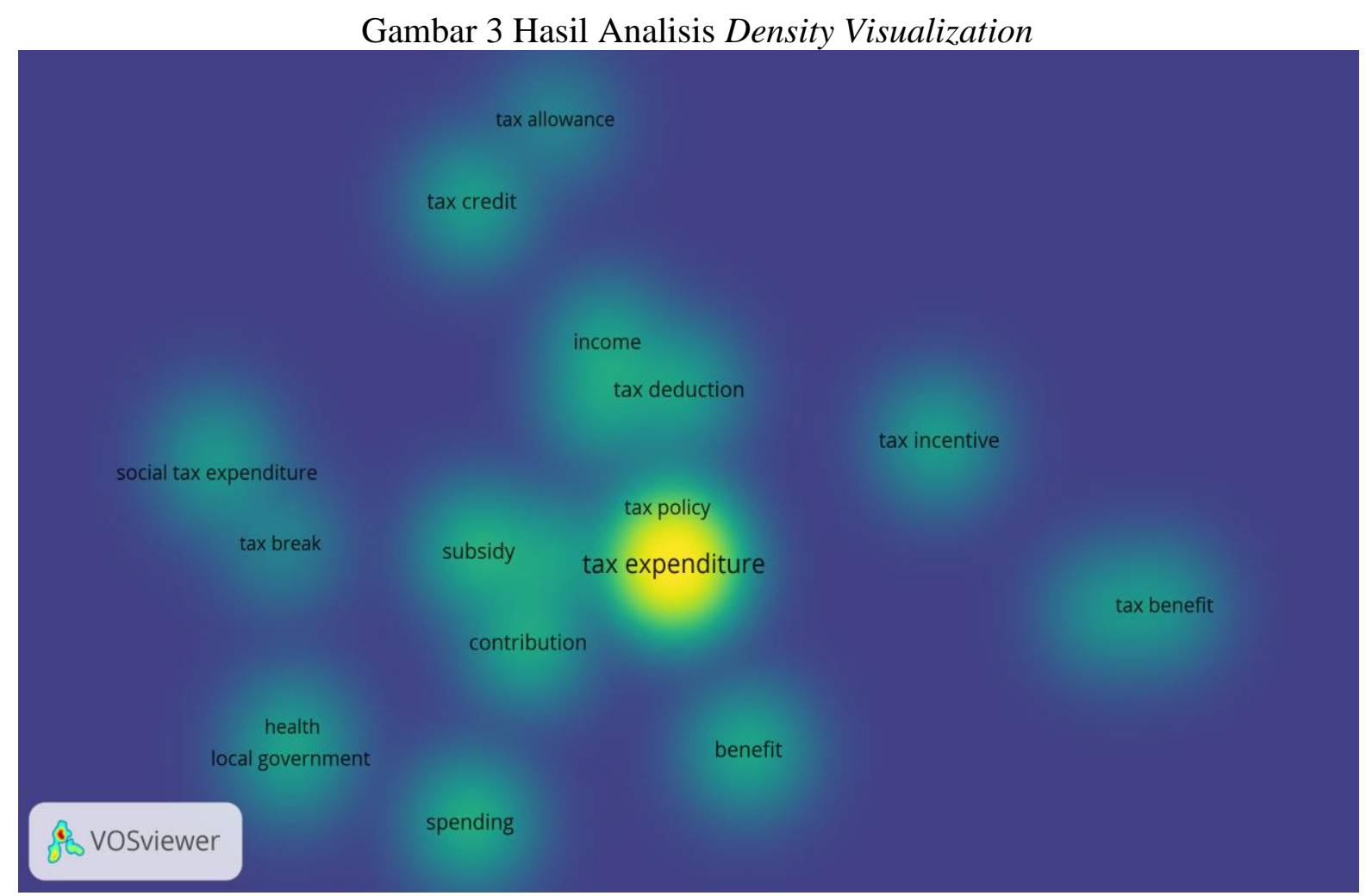

Undang-undang yang baru diundangkan umumnya terdapat topik-topik yang masih jarang diteliti. Dengan diterbitkan Undang-undang tentang Harmonisasi Peraturan Perpajakan, imbalan kepada karyawan dalam bentuk natura yang semula tidak boleh dikurangkan dari penghasilan bruto (nondeductible) sekarang dapat dikurangkan (deductible). Hal ini membuka peluang untuk dilakukan topik-topik penelitian yang masih jarang diteliti.

\section{PENUTUP \\ Simpulan}

Hasil analisis bibliometrik atas penelitian belanja perpajakan selama 20 tahun terakhir dapat diklasifikasikan menjadi empat klaster, yaitu penelitian belanja pajak dikaitkan dengan tujuan sosial, belanja pajak dikaitkan dengan manfaat pensiun, belanja pajak dikaitkan dengan sumbangan, dan belanja pajak dikaitkan dengan fasilitas perpajakan atau tujuan ekonomi. Selain itu, studi ini menunjukkan jumlah penelitian terkait belanja pajak tidak banyak dilakukan, dan mulai tahun 2018-2021 menunjukkan adanya peningkatan. Dengan diterbitkan peraturan perpajakan yang baru, seperti Undang-undang tengan Harmonisasi Peraturan Perpajakan, membuka peluang topik-topik baru terkait belanja pajak yang masih jarang diteliti.

Penelitian ini memiliki beberapa kelemahan. Jumlah artikel penelitian yang dianalisis pada studi ini hanya 52. Biasanya analisis bibliometrik dilakukan atas data kepustakaan dalam jumlah besar.

\section{Saran}

Penelitian analisis bibliometri yang akan datang dapat dilakukan dengan menambah jangka waktu penerbitan sehingga diperoleh artikel penelitian yang dianalisis dalam jumlah cukup banyak. Analisis bibliometrik juga bisa dilakukan pada topik-topik lain yang banyak diteliti, misalnya penghindaran pajak, sehingga dapat dikumpulkan artikel penelitian dalam jumlah yang cukup besar. Selain itu, analisis bibliometrik dapat digunakan aplikasi analisis bibliometrik yang lebih lengkap, misalnya biblioshiny. 


\section{EDUCORETAX}

Volume 1 No. 4, Desember 2021

\section{DAFTAR PUSTAKA}

Anderson, J \& Minarik, J. (2006). Design Choices for Fiscal Policy Rules. OECD Journal on Budgeting, 5(4).

Badan Kebijakan Fiskal. (2020). Laporan Belanja Pajak 2019.

Burton, M., \& Sadiq, K. (2013). Tax Expenditure Management: A Critical Assessment. Cambridge University Press.

Burton, M. (2010). Tax expenditure management: A critical assessment. In Tax Expenditure Management: A Critical Assessment. https://doi.org/10.1017/CBO9780511910142

Donthu, N., Kumar, S., Mukherjee, D., Pandey, N., \& Lim, W. M. (2021). How to conduct a bibliometric analysis: An overview and guidelines. Journal of Business Research, 133(April), 285-296. https://doi.org/10.1016/j.jbusres.2021.04.070

Fahimnia, B., Sarkis, J., \& Davarzani, H. (2015). Green supply chain management: A review and bibliometric analysis. In International Journal of Production Economics (Vol. 162). Elsevier. https://doi.org/10.1016/j.ijpe.2015.01.003

Fink, A. (2005). Conducting Research Literature Reviews. From the Internet to Paper. SAGE Publications Inc., Los Angeles.

Garza-Reyes, J. (2015). Lean and green - a systematic review of the state of the art literature. Journal of Cleaner Production, 102.

Harriss, C. (1975). Philanthropy and the tax expenditure concept. Journal (National Association for Hospital Development (U.S.)), 2-3. https://api.elsevier.com/content/abstract/scopus_id/0016518030

Heersmink, R., Hoven, J., Van Den, E., Van Den, N.J. and Berg, J. (2010). Bibliometric Mapping of Computer and Information Ethics.

International Monetary Fund. (2007). Manual on Fiscal Transparency. https://www.imf.org/external/np/pp/2007/eng/051507m.pdf

Kraan, D. (2004). Off-budget and Tax Expenditures. OECD Journal on Budgeting, 4(1).

OECD. (2010). Tax Expenditures in OECD Countries. OECD Publication, Paris.

OECD. (2021). Revenue Statistics in Asia and the Pacific. https://www.oecd.org/tax/taxpolicy/revenue-statistics-asia-and-pacific-indonesia.pdf

Tranfield, D., Denyer, D. and Smart, P. (2003). Towards a methodology for developing evidenceinformed management knowledge by means of systematic review. British Journal of Management, 14.

van Eck, N. J., \& Waltman, L. (2017). Citation-based clustering of publications using CitNetExplorer and VOSviewer. Scientometrics, 111(2), 1053-1070. https://doi.org/10.1007/s11192-017-2300-7 


\section{EDUCORETAX}

Volume 1 No. 4, Desember 2021

Lampiran Daftar Artikel Hasil Penelusuran Akhir

\begin{tabular}{|c|c|c|c|c|}
\hline No & Penulis & Judul Artikel & Jurnal & $\begin{array}{c}\text { Tahun } \\
\text { Penerbitan }\end{array}$ \\
\hline 1 & Q. Ahmed & $\begin{array}{l}\text { A test of relative efficacy of tax expenditures and direct expenditures a neo- } \\
\text { classical approach }\end{array}$ & Journal of Development Economics & 2001 \\
\hline 2 & J.L. Mikesell & $\begin{array}{l}\text { Tax expenditure budgets, budget policy, and tax policy: Confusion in the } \\
\text { states }\end{array}$ & Public Budgeting and Finance & 2002 \\
\hline 3 & K.I. Jen & Tax expenditures in Michigan: A comparison to federal findings & Public Budgeting and Finance & 2002 \\
\hline 4 & E. Saez & The optimal treatment of tax expenditures & Journal of Public Economics & 2004 \\
\hline 5 & D. Salisbury & The mutuality of employee benefits and tax expenditures & Generations & 2005 \\
\hline 6 & C. Blanchard & Shadow welfare II: Tax expenditures and corporate welfare in the states & Social Policy Journal & 2006 \\
\hline 7 & J. Stallmann & $\begin{array}{l}\text { Impacts of tax \&amp; expenditure limits on local governments: Lessons from } \\
\text { Colorado and Missouri }\end{array}$ & $\begin{array}{l}\text { Journal of Regional Analysis and } \\
\text { Policy }\end{array}$ & 2007 \\
\hline 8 & B. Sicsú & $\begin{array}{l}\text { Tax expenditures with health care in Brazil: The behavior between the years } \\
1996 \text { and } 2003\end{array}$ & Revista de Economia Politica & 2008 \\
\hline 9 & E. Greulich & $\begin{array}{l}\text { Housing subsidies and tax expenditures: The case of mortgage credit } \\
\text { certificates }\end{array}$ & $\begin{array}{l}\text { Regional Science and Urban } \\
\text { Economics }\end{array}$ & 2009 \\
\hline 10 & A. Stebbing & $\begin{array}{l}\text { Universal welfare by other means? Social tax expenditures and the Australian } \\
\text { dual welfare state }\end{array}$ & Journal of Social Policy & 2010 \\
\hline 11 & E.D. Kleinbard & Tax expenditure framework legislation & National Tax Journal & 2010 \\
\hline 12 & N. Eissa & Redistribution and tax expenditures: The earned income tax credit & National Tax Journal & 2011 \\
\hline 13 & D. Ackerman & Tax expenditures for noncash charitable contributions & National Tax Journal & 2011 \\
\hline 14 & J.M. Poterba & Introduction: Economic analysis of tax expenditures & National Tax Journal & 2011 \\
\hline 15 & R. Altshuler & Reconsidering tax expenditure estimation & National Tax Journal & 2011 \\
\hline 16 & R. Carroll & Income versus consumption tax baselines for tax expenditures & National Tax Journal & 2011 \\
\hline 17 & S.J. Guthrie & U.S. Defense contracts during the tax expenditure battles of the 1980s & National Tax Journal & 2011 \\
\hline 18 & I.Z. Lurie & Long-run changes in tax expenditures on $401(\mathrm{~K})$-type retirement plans & National Tax Journal & 2011 \\
\hline 19 & L.E. Burman & $\begin{array}{l}\text { Tax expenditures, the size and efficiency of government, and implications for } \\
\text { budget reform }\end{array}$ & Tax Policy and the Economy & 2012 \\
\hline
\end{tabular}




\section{EDUCORETAX}

Volume 1 No. 4, Desember 2021

\begin{tabular}{|c|c|c|c|c|}
\hline No & Penulis & Judul Artikel & Jurnal & $\begin{array}{c}\text { Tahun } \\
\text { Penerbitan }\end{array}$ \\
\hline 20 & A. Halkyard & $\begin{array}{l}\text { Tax incentives to encourage migration of skilled labour: Another tax } \\
\text { expenditure or a failure of tax residence? }\end{array}$ & eJournal of Tax Research & 2013 \\
\hline 21 & C. Faricy & $\begin{array}{l}\text { Public Attitudes Toward Social Spending in the United States: The } \\
\text { Differences Between Direct Spending and Tax Expenditures }\end{array}$ & Political Behavior & 2014 \\
\hline 22 & J. Goldin & Tax expenditure salience & American Law and Economics Review & 2014 \\
\hline 23 & J. Haselswerdt & $\begin{array}{l}\text { The Lifespan of a Tax Break: Comparing the Durability of Tax Expenditures } \\
\text { and Spending Programs }\end{array}$ & American Politics Research & 2014 \\
\hline 24 & S. Haulotte & Reduce the tax expenditures: A way of reform? & $\begin{array}{l}\text { Reflets et Perspectives de la Vie } \\
\text { Economique }\end{array}$ & 2014 \\
\hline 25 & A. Albarea & $\begin{array}{l}\text { Accounting for tax evasion profiles and tax expenditures in microsimulation } \\
\text { modelling. the betamod model for personal income taxes in Italy }\end{array}$ & $\begin{array}{l}\text { International Journal of } \\
\text { Microsimulation }\end{array}$ & 2015 \\
\hline 26 & I. Ayres & Using the false claims act to remedy tax-expenditure fraud & Duke Law Journal & 2016 \\
\hline 27 & H. Kingi & $\begin{array}{l}\text { The Effect of Tax Expenditures on Automatic Stabilizers: Methods and } \\
\text { Evidence }\end{array}$ & Journal of Empirical Legal Studies & 2017 \\
\hline 28 & M. Romli & $\begin{array}{l}\text { Tax expenditure analysis and reporting: An analysis of selected SME tax } \\
\text { programs in Malaysia }\end{array}$ & $\begin{array}{l}\text { International Journal of Economic } \\
\text { Research }\end{array}$ & 2017 \\
\hline 29 & L. Kaplow & A distribution-neutral perspective on tax expenditure limitations & Tax Policy and the Economy & 2017 \\
\hline 30 & O.V. Bogacheva & Tax expenditures management in OECD countries & $\begin{array}{l}\text { World Economy and International } \\
\text { Relations }\end{array}$ & 2017 \\
\hline 31 & S. Avram & $\begin{array}{l}\text { Who benefits from the 'hidden welfare state'? The distributional effects of } \\
\text { personal income tax expenditure in six countries }\end{array}$ & Journal of European Social Policy & 2018 \\
\hline 32 & B. Lewis & $\begin{array}{l}\text { Local Government Form in Indonesia: Tax, Expenditure, and Efficiency } \\
\text { Effects }\end{array}$ & $\begin{array}{l}\text { Studies in Comparative International } \\
\text { Development }\end{array}$ & 2018 \\
\hline 33 & S. Barrios & The Fiscal Effects of Work-related Tax Expenditures in Europe & Public Finance Review & 2018 \\
\hline 34 & C. Ocké-Reis & $\begin{array}{l}\text { Financial sustainability of the Brazilian health system and health-related tax } \\
\text { expenditures }\end{array}$ & Ciencia e Saude Coletiva & 2018 \\
\hline 35 & S. Sudsawasd & Corporate income tax expenditures in Thailand & Thailand and the World Economy & 2018 \\
\hline 36 & J. Kulik & $\begin{array}{l}\text { Tax Expenditure Limitations (TELs) and State Expenditure Structure in the } \\
\text { USA }\end{array}$ & Public Organization Review & 2018 \\
\hline 37 & P. Kirschnerová & Are Tax Expenditures of Individuals Only a Tool of Tax Optimisation? & $\begin{array}{l}\text { International Advances in Economic } \\
\text { Research }\end{array}$ & 2018 \\
\hline
\end{tabular}




\section{EDUCORETAX}

Volume 1 No. 4, Desember 2021

\begin{tabular}{|c|c|c|c|c|}
\hline No & Penulis & Judul Artikel & Jurnal & $\begin{array}{c}\text { Tahun } \\
\text { Penerbitan }\end{array}$ \\
\hline 38 & R. Branco & $\begin{array}{l}\text { The Golden Age of Tax Expenditures: Fiscal Welfare and Inequality in } \\
\text { Portugal (1989-2011) }\end{array}$ & New Political Economy & 2019 \\
\hline 39 & D. Splinter & $\begin{array}{l}\text { The Mortgage Interest Deduction: Causes of Fluctuations in a Procyclical Tax } \\
\text { Expenditure }\end{array}$ & Public Finance Review & 2019 \\
\hline 40 & B. Jun & $\begin{array}{l}\text { Effects of socio-economic factors on governmental tax expenditures for } \\
\text { private pensions in selected OECD countries }\end{array}$ & Singapore Economic Review & 2019 \\
\hline 41 & A. Redonda & Tax expenditure and the treatment of tax incentives for investment & Economics & 2019 \\
\hline 42 & S. Barrios & The fiscal and equity impact of social tax expenditures in the EU & Journal of European Social Policy & 2020 \\
\hline 43 & B.J. Malin & $\begin{array}{l}\text { Advertising as a Tax Expenditure: The Tax Deduction for Advertising and } \\
\text { America's Hidden Public Media System }\end{array}$ & Political Economy of Communication & 2020 \\
\hline 44 & J.E. Milne & Renewable Electricity and Tax Expenditures: Lessons from Two Countries & Intertax & 2020 \\
\hline 45 & V. Thuronyi & The Paycheck Protection Programme: A Tax Expenditure in Reverse? & Intertax & 2020 \\
\hline 46 & S. Barrios & $\begin{array}{l}\text { Size and distributional pattern of pension-related tax expenditures in } \\
\text { European countries }\end{array}$ & International Tax and Public Finance & 2020 \\
\hline 47 & L.D.C.B. Bolaños & Income tax in colombia: A view from tax expenditure & $\begin{array}{l}\text { Boletin Mexicano de Derecho } \\
\text { Comparado }\end{array}$ & 2020 \\
\hline 48 & S.d.J.L. Pérez & $\begin{array}{l}\text { When harmful tax expenditure prevails over environmental tax: An } \\
\text { assessment on the } 2014 \text { mexican fiscal reform }\end{array}$ & Sustainability (Switzerland) & 2021 \\
\hline 49 & Y. Provencher & Social tax expenditures in Quebec (Canada): The state of play & International Journal of Social Welfare & 2021 \\
\hline 50 & T.A. Vershilo & $\begin{array}{l}\text { Tax expenditures of public legal education in the system of budget revenues } \\
\text { and expenditures }\end{array}$ & Gosudarstvo i Pravo & 2021 \\
\hline 51 & M. Surugiu & $\begin{array}{l}\text { Taxes, expenditure and development nexus: A panel VECM analysis on } \\
\text { Romanian nuts } 2 \text { regions }\end{array}$ & $\begin{array}{l}\text { European Journal of Sustainable } \\
\text { Development }\end{array}$ & 2021 \\
\hline 52 & C.D. Tesser & $\begin{array}{l}\text { Obstacles to sus universalization: Tax expenditures, labor union demands and } \\
\text { health insurance state subsidy }\end{array}$ & Ciencia e Saude Coletiva & 2021 \\
\hline
\end{tabular}

